\title{
EVALUASI TERHADAP IMPLEMENTASI LINTAS MINAT DALAM KELOMPOK PEMINATAN DI SMA/MA KECAMATAN LEMBANG
}

\author{
Anggi Riafadilah dan Laksmi Dewi \\ Universitas Pendidikan Indonesia \\ e-mail: anggiriafadilah@gmail.com
}

\begin{abstract}
Abstrak
Kurikulum 2013 yang berlaku di Indonesia, memuat lintas minat yang tujuannya untuk memberikan wadah bagi peserta didik dalam memperluas pilihan minat dan bakat di luar pilihan minat sesuai dengan minat-bakatnya, dan kemampuan akademik yang mempertimbangkan nilai raport, nilai ujian nasional, serta rekomendasi guru bimbingan konseling di SMP atau MTs. Berdasarkan studi pendahuluan, pelaksanaan lintas minat ini belum efektif. Maka dari itu, peneliti mengevaluasi implementasi lintas minat dalam kelompok peminatan di SMA dan MA yang ada di Kecamatan Lembang. Teknik pengumpulan data dalam penelitian ini adalah wawancara dan studi dokumentasi. Hasil penelitian ini adalah pelaksanaan lintas minat dalam kelompok peminatan di SMA dan MA yang ada di Lembang belum sesuai dengan pedoman yang dibuat oleh kemendikbud. Ketidaksesuaian tersebut dalam hal proses pemilihan mata pelajaran dalam lintas minat. Sekolah menentukan mata pelajaran apa yang akan peserta didik dapatkan, padahal seharusnya peserta didik sendiri lah yang harus memilih mata pelajaran dalam lintas minat tersebut. Hal ini berimbas pada hasil belajar peserta didik. Faktor yang menyebabkan implementasi lintas minat tidak sesuai dengan pedoman kemendikbud diantaranya adalah jumlah guru, jumlah peserta didik, juga sarana dan prasarana yang terbatas.
\end{abstract}

Kata Kunci: evaluasi, lintas minat, kelompok peminatan

\section{EVALUATION OF THE IMPLEMENTATION OF ELECTIVES IN INTEREST GROUPS IN SMA/ MA IN THE DISTRICT OF LEMBANG}

\begin{abstract}
2013 curriculum in Indonesia, contains a cross-section of interests who aim to provide a platform for learners in expanding choice of interest and talent outside the selection of interest in accordance with the interest-his talent, and academic ability who are considering the value of report cards, national examinations, as well as recommendations for guidance counseling teacher in junior high or MTS. Based on preliminary studies, the implementation of the cross-interest has not been effective. Therefore, researchers are evaluating the implementation of the cross-interest in peminatan group in high school and MA that is in the Sub District of Lembang. Data collection techniques in the study was an interview and documentation study. The results of this research is the implementation of the cross-interest in the interest group in high school and MA are there in the Lembang has not been in accordance with the guidelines made by the kemendikbud. The discrepancy in terms of the process of the selection of subjects in the traffic of interest. The school determines the subjects what will the learners get, when it should learners themselves who have to choose subjects in the interest of cross. This imposes the learning results of learners. The factors that led to the implementation of the cross-interest does not comply with the guidelines of kemendikbud including the number of teachers, the number of learners, as well as limited facilities and infrastructure.
\end{abstract}

Keywords: evaluation, electives, interest group 


\section{PENDAHULUAN}

Di Indonesia, kurikulum terus menerus berubah sesuai perkembangan jaman. Pengembangan kurikulum tersebut berlandaskan pada landasan ilmu pengetahuan dan teknologi (Hamid, 2012). Perubahan kurikulum di Indonesia setelah kemerdekaan 1945 mengalami beberapa kali perubahan, dimulai dari Rencana pelajaran tahun 1947, Kurikulum 1952, Kurikulum 1964, Kurikulum 1968, Kurikulum 1975/1976, Kurikulum 1984, Kurikulum 1994, Kurikulum Berbasis Kompetensi 2004, Kurikulum Tingkat Satuan Pendidikan 2006, dan Kurikulum 2013 (Hidayat, 2013).

Pada saat ini, kurikulum yang berlaku di Indonesia adalah kurikulum 2013. Kurikulum 2013 disusun untuk mempersiapkan lulusan menghadapi era globalisasi (Karli, 2014). Khusus di SMA dan MA, ada perbedaan dari kurikulum sebelumnya, yakni dengan adanya program kulikuler lintas minat. Tujuan dari lintas minat di SMA dan MA adalah untuk memberikan wadah bagi peserta didik memperluas pilihan minat dan bakat di luar pilihan minat (Permendikbud nomor 64 tahun 2014).

Artinya, ketika peserta didik yang memilih kelompok peminatan Matematika dan Ilmu-Ilmu Alam (MIPA), maka dapat mengambil beberapa mata pelajaran dari Peminatan Ilmu-ilmu Sosial (IPS) dan mata pelajaran dari Peminatan Ilmu-Ilmu Bahasa dan Budaya sesuai dengan keinginan, minat, dan bakat.

Dalam naskah model peminatan dan lintas minat yang dibuat kemendikbud tahun 2017, dikatakan bahwa dalam menentukan mata pelajaran pada lintas minat, peserta didik diberi formulir yang harus diisi pada saat sebelum diterima atau setelah diterima di SMA atau MA. Formulir tersebut berisi pertanyaan mata pelajaran apa yang menjadi minat atau keinginan peserta didik di luar dari mata pelajaran peminatan. Dengan pengisian formulir tersebut, peserta didik diharapkan dapat memilih mata pelajaran sesuai dengan minat dan bakatnya (Naskah
Model Peminatan dan Lintas Minat Kemendikbud, 2017).

Peneliti melakukan wawancara tidak resmi terhadap guru biologi yang mengajar di kelas lintas minat salah satu sekolah yang ada di Lembang. Guru tersebut mengatakan bahwa implementasi lintas minat tidak sesuai dengan pedoman dari kemendikbud. Pedoman dari kemendikbud yakni dalam penentuan lintas minat, peserta didik mengisi formulir yang disediakan sekolah yang harus diisi sesuai dengan minat, bakat, arahan orang tua dan masukan dari guru bimbingan konseling. Sedangkan, di sekolah tersebut pemilihan mata pelajaran pada lintas minat ditentukan oleh sekolah. Guru tersebut mengatakan ketika belajar biologi di kelas IPS, perhatian peserta didik dalam pembelajaran tidak maksimal karena mata pelajaran biologi tersebut tidak sesuai dengan keinginan dan minat, tetapi karena terpaksa.

Dengan adanya latar belakang di atas, peneliti mencoba mengevaluasi kesesuaian antara lintas minat dalam kelompok peminatan yang ada di permendikbud nomor 64 tahun 2014, dengan keadaan di lapangan, khususnya di SMA dan MA yang ada di Kecamatan Lembang. Hal yang menjadi tujuan umum dalam penelitian ini adalah mengevaluasi implementasi lintas minat dalam kelompok peminatan di SMA dan MA yang ada di Kecamatan Lembang. Sedangkan tujuan khusus dari penelitian ini adalah a) mengetahui persiapan pengembangan lintas minat di SMA dan MA yang ada di Kecamatan Lembang, b) mengetahui kesesuaian proses pemilihan mata pelajaran pada lintas minat di SMA dan MA yang ada di Kecamatan Lembang, c) mengetahui hasil belajar peserta didik dalam mata pelajaran lintas minat di SMA dan MA yang ada di Kecamatan Lembang, dan d) mengetahui pendapat siswa dan guru mengenai pelaksanaan lintas minat di SMA dan MA yang ada di Kecamatan Lembang. 


\section{METODE}

Dalam penelitian ini, penulis menggunakan pendekatan penelitian kualitatif. Desain penelitian yang diguna-kan dalam penelitian ini adalah penelitian evaluatif. Penelitian evaluatif merupakan suatu desain dan prosedur evaluasi dalam mengumpulkan dan menganalisis data secara sistematik untuk menentukan nilai atau manfaat dari suatu praktik pendidikan (Sukmadinata, 2005). Dalam penelitian evaluatif, nilai atau manfaat dari hasil analisis adalah dengan membandingkan antara standar atau kriteria tertentu dengan hasil penelitian di lapangan (sekolah). Yang menjadi standar dalam penelitian ini adalah model peminatan dan lintas minat yang dikeluarkan oleh Kementrian Pendidikan dan Kebudayaan pada tahun 2017.

Penelitian evaluatif yang dilakukan pada penelitian ini dengan mengadopsi Goal Oriented Evaluation Model. Model ini pertama kali dibuat oleh Tyler. Model evaluasi kurikulum ini menekankan bahwa evaluasi yang baik harus membuktikan kesesuaian antara kurikulum dengan tujuan pendidikan (Chall \& Stone, 1987).

Teknik dalam mengumpulkan data adalah wawancara sebagai teknik pengumpul data primer dan studi dokumen sabagai teknik pengumpul data sekunder (Creswell, 2009). Dalam penelitian ini, cara untuk menguji keabsahan data dengan menggunakan triangulasi sumber. Triangulasi sumber berarti mendapatkan data dari sumber yang berbeda-beda dengan teknik yang sama (Sugiyono, 2009). Teknik yang digunakan dalam penelitian ini adalah koding, kategorisasi, dan verifikasi data (Alwasilah, 2015; Daryanto, 2013; Suryanto, 2012; Ali, 2014).

\section{HASIL DAN PEMBAHASAN Hasil}

Hasil penelitian ini berlandaskan pada tujuan dari penelitian. Tujuan umum dari penelitian ini yakni mengevaluasi implementasi lintas minat dalam kelompok peminatan di SMA dan MA yang ada di Kecamatan Lembang. Implementasi lintas minat pada kelompok peminatan di SMA dan MA yang ada di Lembang belum sesuai dengan aturan yang dibuat kemendikbud tahun 2017. Faktor yang menyebabkan ketidaksesuaian implementasi lintas minat dalam kelompok peminatan di SMA dan MA yang ada di Lembang adalah faktor guru, peserta didik, dan sarana dan prasarana yang dimiliki sekolah.

Sedangkan tujuan khusus dari penelitian ini adalah a) mengetahui persiapan pengembangan lintas minat di SMA dan MA yang ada di Kecamatan Lembang, b) mengetahui kesesuaian proses pemilihan mata pelajaran pada lintas minat di SMA dan MA yang ada di Kecamatan Lembang, c) mengetahui hasil belajar peserta didik dalam mata pelajaran lintas minat di SMA dan MA yang ada di Kecamatan Lembang, dan d) mengetahui pendapat siswa dan guru mengenai pelaksanaan lintas minat di SMA dan MA yang ada di Kecamatan Lembang.

Hasil penelitian untuk tujuan penelitian yang pertama adalah wakil kepala sekolah bidang kurikulum dan guru Bimbingan Konseling (BK) di SMA dan MA yang ada di Kecamatan Lembang sudah memahami akan konsep lintas minat dalam kelompok peminatan yang sesuai dengan kemendikbud mengenai model peminatan dan lintas minat SMA dan MA tahun 2017.

Hasil penelitian untuk tujuan penelitian yang kedua adalah proses pemilihan mata pelajaran pada lintas minat dalam kelompok peminatan di SMA dan MA Kecamatan Lembang tidak sesuai dengan aturan kemendikbud mengenai model peminatan dan lintas minat SMA dan MA tahun 2017.

Hasil penelitian untuk tujuan penelitian yang ketiga adalah hasil belajar pada mata pelajaran dalam lintas minat di kelas XI MIPA dan IPS di SMAN 1 Lembang berbeda. Untuk di kelas XI MIPA, hasil belajar pada mata pelajaran lintas minat yang sekolah tentukan cenderung lebih memuaskan dibandingkan dengan kelas XI IPS. Sedangkan untuk kelas XI IPS, hasil belajar yang mereka dapat cenderung tidak memuaskan, terbukti 
dengan banyaknya peserta didik yang nilai ulangan harian, UTS, dan UAS di bawah KKM (Kriteria Ketuntasan Minimal). Berbeda dengan hasil belajar peserta didik di MA Al-Amanah Lembang, hasil belajar peserta didik di MA Al-Amanah sangat memuaskan.

Hasil penelitian untuk tujuan penelitian yang keempat adalah guru di SMA dan MA yang ada di Kecamatan Lembang sepakat bahwa pelaksanaan lintas minat yang dibuat oleh kemendikbud sudah baik. Hanya saja, dengan dibuatnya aturan tersebut harus mempertimbangkan pula keadaan guru, peserta didik, sarana dan prasarana yang ada di sekolah.

\section{Pembahasan}

Hasil penelitian Oktadiani (2014), menyebutkan bahwa di kelas X MIPA 5 dan $X$ MIPA 6 SMA Negeri 1 Pontianak khususnya mata pelajaran ekonomi, kurang sesuai dengan minat. Dengan kurang sesuainya minat peserta didik, maka beberapa peserta didik merasa kurang perlu mendalami ilmu ekonomi, karena tidak sesuai dengan keinginan. Hal ini seharusnya tidak terjadi karena kemdikbud sudah mengatur dengan jelas bagaimana prosedur lintas minat dimulai dari perencanaan sampai lahirnya atau dibukanya mata pelajaran lintas minat (Naskah Model Peminatan dan Lintas Minat Kemdikbud, 2017).

Kemudian, dalam penelitian Raharjeng (2014) mengenai pelaksanaan layanan peminatan di SMAN 2 Lamongan, mengatakan, lintas minat merupakan faktor penghambat dalam implementasi pelaksanaan layanan peminatan. Selain kekurangan lintas minat yang dikatakan sebelumnya, ada pula penelitan yang mengatakan kelebihan dai lintas minat. Dalam penelitian yang dilakukan Febria (2014), mengatakan bahwa beberapa sekolah SMA di Surabaya berpendapat bahwa adanya lintas minat sangat membantu Guru BK dalam mengatur peminatan jika dipertengahan semester peserta didik salah masuk jurusan.

Hasil survei yang dilakukan Meliawati (2017) mengatakan bahwa pelaksanaan lintas minat di seluruh SMA Negeri se-Kota Malang sudah sesuai dengan acuan pemerintah. Tetapi ada beberapa hambatan, hambatan tersebut berupa sulitnya mengkondisikan peserta didik, kendala penggunaan media, pelaksanaan praktikum, dan kendala sarana prasarana ruang kelas. Kemudian hasil penelitian yang dilakukan Panjaitan (2017) mengatakan bahwa minat belajar biologi pada siswa lintas minat kelas X IIS SMA Negeri 5 Kota Jambi memiliki minat yang tinggi dalam mengikuti pelajaran biologi.

Dari kelima penelitian di atas, dapat dikatakan bahwa implementasi lintas minat memiliki beberapa faktor penghambat, diantaranya peserta didik, dan sarana dan prasarana yang dimiliki sekolah. Apabila dibandingkan dengan penelitian yang dilakukan peneliti, ada tambahan penghambat implementasi lintas minat dalam kelompok peminatan di SMA dan MA yang ada di Kecamatan Lembang, yakni faktor guru.

Dalam permendikbud nomor 23 tahun 2017 tentang Hari Sekolah dikatakan bahwa hari sekolah dilaksanakan selama 8 jam sehari atau 40 jam selama seminggu. Dengan adanya aturan tersebut, maka jumlah jam mengajar guru pun harus disesuaikan yakni selama 40 jam dalam satu minggu untuk memenuhi beban mengajar. Dari aturan tersebut berimbas pada implementasi lintas minat di Kecamatan Lembang, di SMAN 1 Lembang jumlah guru bidang IPS dan MIPA tidak seimbang, sedangkan di MA Al-Amanah Lembang mengalami kekurangan guru mata pelajaran.

Jumlah kelompok peminatan di SMAN 1 Lembang untuk kelas XI MIPA sebanyak 11 rombongan belajar (rombel), sedangkan untuk kelas XI IPS sebanyak 7 kelas. Dalam penentuan kelompok peminatan ini, ada beberapa kelas yang memang tidak sesuai dengan keinginannya. Menurut wakil kepala sekolah bidang kurikulum SMAN 1 Lembang, seharusnya jumlah kelas IPS lebih banyak dibandingkan kelas MIPA, tetapi karena jumlah guru bidang MIPA lebih banyak, maka dipaksalah beberapa peserta didik untuk dimasukkan ke dalam kelompok peminatan MIPA. Begitupun implementasi lintas minat, walaupun kelompok peminatan MIPA sudah ditambah, tetapi guru bidang 
MIPA masih kekurangan jam. Maka, sekolah dengan terpaksa memasukkan peserta didik ke dalam mata pelajaran lintas minat sesuai dengan guru yang jumlah jam mengajarnya kurang.

Di MA Al-Amanah Lembang, hanya membuka satu kelompok peminatan yakni MIPA. Kelas XI memiliki 1 kelas. Jumlah mata pelajaran pada lintas minat yang ditentukan sekolah berjumlah dua mata pelajaran yakni Bahasa Inggris (conversation) dan Bahasa Arab (conversation). Kedua mata pelajaran ini dipilih sekolah karena guru yang tersedia hanya guru Bahasa Inggris dan Bahasa Arab, maka sekolah memutuskan mata pelajaran pada lintas minat lebih dikhususkan ke materi dalam bentuk conversation (percakapan).

Untuk faktor peserta didik, di MA AlAmanah tidak menjadi faktor penghambat implementasi lintas minat dalam kelompok peminatan. Terbukti dengan hasil ulangan harian, penilaian tengah semester dan penilaian akhir semester sangat memuaskan. Sedangkan, di SMAN 1 Lembang, peserta didik sangat berpengaruh dalam implementasi lintas minat dalam kelompok peminatan. Di kelas XI MIPA, nilai lintas minat (sosiologi) memiliki nilai ulangan harian, penilaian tengah semester dan penilaian akhir semester sangat memuaskan, sebaliknya di kelas XI IPS, nilai lintas minat (fisika) memiliki nilai ulangan harian, penilaian tengah semester dan penilaian akhir semester tidak memuaskan terbukti dengan banyaknya peserta didik yang di bawah KKM (Kriteria Ketuntasan Minimal).

Guru mata pelajaran lintas minat sosiologi berpendapat bahwa di kelas MIPA, guru dengan sangat mudah menyampaikan materi dengan menggunakan model-model pembelajaran yang diharuskan pada kurikulum 2013 (project based learning, problem based learning, dan discovery learning) karena daya tangkap kelas MIPA sangat cepat maka penyampaian materipun dengan mudah guru sampaikan. Sedangkan untuk mata pelajaran lintas minat fisika berpendapat bahwa di kelas IPS, guru sangat sulit menyampaikan materi dengan menggunakan model-model pembelajaran yang diharuskan pada kurikulum 2013 (project based learning, problem based learning, dan discovery learning) karena daya tangkap kelas IPS agak lambat maka penyampaian materipun membutuhkan waktu yang cukup lama agar guru menyampaikan kepada peserta didik denan baik.

\section{PENUTUP}

Berdasarkan hasil penelitian yang telah dilakukan, dapat disimpulkan bahwa implementasi lintas minat dalam kelompok peminatan di SMA dan MA di Kecamatan Lembang belum efektif. Karena tidak sesuai dengan aturan pada naskah model peminatan dan lintas minat yang dibuat kemendikbud tahun 2017. Faktor yang menyebabkan ketidaksesuaian tersebut adalah faktor guru, khususnya dalam hal jumlah. Di SMAN 1 Lembang jumlah guru tidak seimbang antara kelas MIPA dan IPS, untuk di MA Al-Amanah Lembang justru kekurangan guru mata pelajaran. Selain kekurangan dan ketidakseimbangan jumlah guru, jumlah jam guru yang meningkatpun menjadi faktor yang menyebabkan ketidaksesuaian implementasi lintas minat, awalnya hanya 24 jam perminggu menjadi 40 jam mengajar perminggu. Faktor kedua yakni jumlah peserta didik yang tidak sesuai dengan permendikbud nomor 17 tahun 2017 yang seharusnya jumlah peserta didik dalam satu rombongan belajar adalah 20 sampai 36 peserta didik. Faktor yang terakhir adalah sarana dan prasarana yang dimiliki sekolah, kurangnya kelas untuk menampung minat peserta didik, menjadi faktor yang mempengaruhi implementasi lintas minat di Kecamatan Lembang.

\section{UCAPAN TERIMA KASIH}

Penulis mengucapkan terimakasih kepada dosen pembimbing tesis, ibu Dr. Laksmi Dewi, M.Pd yang telah membimbing penulis dalam menyelesaikan artikel ini. Kemudian wakil kepala sekolah bidang kurikulum, guru bimbingan konseling, dan peserta didik di SMAN 1 Lembang dan MA Al-Amanah Lembang yang sudah bersedia melakukan wawancara untuk pengumpulan 
data penelitian. Tidak lupa kedua orangtua yang tiada hentinya mendukung penulis, baik dukungan moril maupun materil.

\section{DAFTAR PUSTAKA}

Ali, M. (2014). Memahami riset perilaku dan sosial. Jakarta: Bumi Aksara.

Alwasilah, A. C. (2015). Pokoknya studi kasus, pendekatan kualitatif. Bandung: PT Kiblat Buku Utama.

Chall, M. and Stone, James. C. (1987). Ralph tyler: education-curriculum development and evaluation. SAGE.

Creswell, J. W. (2009). Research design: qualitative, quantitative, and mixed methods approaches. Newbury Park: Sage Publications.

Daryanto, S. N. (2013). Dinamika Nilai Kerja: Studi Indigenous Karyawan Bersuku Jawa. Journal of Social and Industrial Psychology. ISSN 2252683.

http://journal.unnes.ac.id/sju/index.p $\mathrm{hp} / \mathrm{sip}$.

Febria, R. W. (2014). Survei tentang persepsi dan kesiapan konselor terhadap bimbingan dan konseling berdasarkan kurikulum 2013 di SMA Surabaya Selatan. Jurnal BK UNESA. Surabaya Selatan Volume 04 Nomor 03 Tahun 2014.

Hamid, H. (2012). Pengembangan kurikulum pendidikan. Bandung: CV Pustaka Setia.

Hidayat, S. (2013). Pengembangan kurikulum baru. Bandung: PT Remaja Rosdakarya.

Karli, H. (2014). Perbedaan Kurikulum Tingkat Satuan Pendidikan 2006 dan Kurikulum 2013 untuk Jenjang Sekolah Dasar. Jurnal Pendidikan Penabur - No.22/Tahun ke-13/Juni 2014.

Meliawati, W. (2017). Survei pelaksanaan lintas minat pada mata pelajaran biologi beserta analisis kendala pelaksanaan di sma negeri se kota malang. Tesis tidak diterbitkan, hal 110.

Naskah model peminatan dan lintas minat yang dibuat kemendikbud tahun 2017
Oktadiani, F. S. (2014). Persepsi siswa pada mata pelajaran ekonomi (studi kasus peminatan di sma negeri 1 pontianak). Tesis tidak diterbitkan.

Panjaitan, C. (2017). Analisis minat belajar biologi pada rumpun lintas minat berdasarkan implementasi kurikulum 2013 pada siswa kelas X SMA negeri Kota Malang. Tesis tidak diterbitkan Universitas Jambi.

Permendikbud nomor 64 tahun 2014

Permendikbud nomor 23 tahun 2017 tentang Hari Sekolah

Raharjeng, R. S. (2014). Implementasi kurikulum 2013 bimbingan dan konseling dalam pelaksanaan layanan peminatan peserta didik sma negeri 2 Lamongan tahun ajaran 2013/2014. Jurnal BK. Volume 04 Nomor 03 Tahun 2014, 1 -9.

Sugiyono. (2009). Metode penelitian kuantitatif, kualitatif dan $R \& D$. Bandung: Alfabeta.

Sukmadinata, N. S. (2005). Metode penelitian pendidikan. Bandung: PT Remaja Rosdakarya.

Suryanto, A. (2012). Perilaku pencarian informasi oleh siswa sma negeri 2 magelang. program studi ilmu perpustakaan, fakultas ilmu budaya, Universitas Diponegoro. 